\title{
THE
}

\section{Modeling range dynamics in heterogeneous landscapes: invasion of the hemlock woolly adelgid in eastern North America}

\author{
Matthew C. Fitzpatrick \\ Evan L. Preisser \\ University of California - Davis, preisser@uri.edu \\ Adam Porter \\ Joseph Elkinton \\ Aaron M. Ellison
}

Follow this and additional works at: https://digitalcommons.uri.edu/bio_facpubs

Terms of Use

All rights reserved under copyright.

\section{Citation/Publisher Attribution}

Fitzpatrick, M. C., Preisser, E. L., Porter, A. , Elkinton, J. and Ellison, A. M. (2012), Modeling range dynamics in heterogeneous landscapes: invasion of the hemlock woolly adelgid in eastern North America. Ecological Applications, 22: 472-486. doi: 10.1890/11-0009.1 Available at: https://doi.org/10.1890/ 11-0009.1 


\title{
Modeling range dynamics in heterogeneous landscapes: invasion of the hemlock woolly adelgid in eastern North America
}

\author{
Matthew C. Fitzpatrick, ${ }^{1,2,3,5}$ Evan L. Preisser, ${ }^{2}$ Adam Porter, ${ }^{4}$ Joseph Elkinton, ${ }^{4}$ and Aaron M. Ellison ${ }^{3}$ \\ ${ }^{1}$ University of Maryland Center for Environmental Science, Appalachian Lab, Frostburg, Maryland 21532 USA \\ ${ }^{2}$ Department of Biological Sciences, University of Rhode Island, Kingston, Rhode Island 02881 USA \\ ${ }^{3}$ Harvard University, Harvard Forest, Petersham, Massachusetts 01366 USA \\ ${ }^{4}$ Department of Plant, Soil, and Insect Sciences, University of Massachusetts, Amherst, Massachusetts 01003 USA
}

\begin{abstract}
Range expansion by native and exotic species will continue to be a major component of global change. Anticipating the potential effects of changes in species distributions requires models capable of forecasting population spread across realistic, heterogeneous landscapes and subject to spatiotemporal variability in habitat suitability. Several decades of theory and model development, as well as increased computing power and availability of fine-resolution GIS data, now make such models possible. Still unanswered, however, is the question of how well this new generation of dynamic models will anticipate range expansion. Here we develop a spatially explicit stochastic model that combines dynamic dispersal and population processes with fine-resolution maps characterizing spatiotemporal heterogeneity in climate and habitat to model range expansion of the hemlock woolly adelgid (HWA; Adelges tsugae). We parameterize this model using multiyear data sets describing population and dispersal dynamics of HWA and apply it to eastern North America over a 57year period (1951-2008). To evaluate the model, the observed pattern of spread of HWA during this same period was compared to model predictions. Our model predicts considerable heterogeneity in the risk of HWA invasion across space and through time, and it suggests that spatiotemporal variation in winter temperature, rather than hemlock abundance, exerts a primary control on the spread of HWA. Although the simulations generally matched the observed current extent of the invasion of HWA and patterns of anisotropic spread, it did not correctly predict when HWA was observed to arrive in different geographic regions. We attribute differences between the modeled and observed dynamics to an inability to capture the timing and direction of long-distance dispersal events that substantially affected the ensuing pattern of spread.
\end{abstract}

Key words: Adelges tsugae, hemlock woolly adelgid; bioclimate envelopes; biological invasions; climate change; global warming; landscape epidemiology; metapopulation model; population dynamics; range shift; species distribution models; species migration; spread model.

\section{INTRODUCTION}

Across the globe, species are actively expanding their geographic ranges, some in response to recent climatic change (Walther et al. 2002, Parmesan and Yohe 2003) and others as the result of introductions into new regions (Mack 1996). In order to anticipate the potential effects of ongoing and future changes in the distributions of native and invasive species, there is increasing need to understand which factors influence the dynamics of range expansion and to develop models to forecast population spread. However, species most likely to exhibit dramatic range expansion and to therefore be of greatest interest in management contexts often possess

Manuscript received 4 January 2011; revised 29 August 2011; accepted 10 October 2011. Corresponding Editor: A. D. McGuire.

${ }^{5}$ Present address: University of Maryland Center for Environmental Science, Appalachian Lab, 301 Braddock Road, Frostburg, Maryland 21532 USA.

E-mail: mfitzpatrick@umces.edu characteristics that make changes in their distributions difficult to predict, notably spread driven by rare, longdistance dispersal events and rapid population growth (Hastings et al. 2005). The interaction between landscape heterogeneity and spread dynamics adds a layer of complexity that is rarely incorporated into models, but may be critical to developing adequate forecasts of range expansion at regional scales (Turner et al. 1993, With 2002, Hastings et al. 2005).

Multiple approaches have been used to model changes in species distributions at a variety of temporal and spatial scales. Given their relative simplicity, computational efficiency, and benign data requirements, species distribution models (SDMs) remain a common technique generally regarded as providing a useful first estimate of potential changes in species distributions at the broadest of spatial extents (Pearson and Dawson 2003). SDMs rely on static correlations between species occurrences and environmental characteristics to predict distributions of species. In essence, SDMs produce mapped predictions of the geographic ranges that 
species would occupy if distributions were constrained by abiotic factors alone. Such correlative models will accurately predict changes in species distributions only if the observed species-environment relationships correspond to processes and factors that constrain the range and these relationships remain unchanged in new ecological settings (Guisan and Thuiller 2005, Broennimann et al. 2007, Fitzpatrick et al. 2007). Even when these conditions are met, SDMs rarely incorporate the underlying processes that drive spread dynamics, most notably population and dispersal processes (Gallien et al. 2010). Therefore, although SDMs can predict potential changes in geographic distributions of species though time (e.g., Fitzpatrick et al. 2008), unless predictions from SDMs are coupled to dynamic population growth and dispersal models (e.g., Keith et al. 2008, Anderson et al. 2009), they can reveal little about the extent to which spreading populations could actually attain these changes. As a result, SDMs are more suited to mapping a species' potential range within a study region than to determining the probability of establishment or the likely timing of arrival in a specific location.

Forecasting actual changes in the geographic distribution of populations requires the development of models that integrate habitat suitability with dynamic dispersal and population processes (Thuiller et al. 2008, Elith et al. 2010, Franklin 2010, Huntley et al. 2010). General theoretical models of spread that incorporate population growth and dispersal have been used by ecologists for decades (e.g., Fisher 1937, Skellam 1951, Kot et al. 1996), but these existing models rarely consider temporal and spatial heterogeneity in habitat suitability that may profoundly influence spread dynamics (Higgins et al. 1996, With 2002, Meentemeyer et al. 2008, 2011). As a result, general models of spread provide considerable theoretical insight but offer little in terms of applied practical utility and specific predictions regarding range expansion in a region of interest.

Developing models of range expansion that incorporate the dynamics of population growth and dispersal, as well as shifting habitat suitability and realistic landscape heterogeneity, could substantially improve our ability to understand and predict range expansion (Thuiller et al. 2008). Few such models have been developed and applied to large heterogeneous landscapes (for notable exceptions, see Keith et al. 2008, Anderson et al. 2009, and Meentemeyer et al. 2011). Because long-term observational data sets documenting range expansion are rare, there have been even fewer direct comparisons of predictions from dynamic models to long-term records of spread (but see Pitt et al. 2009). Although incorporating greater realism into models may improve our understanding of range expansion, it is still unclear whether this improved understanding will translate into better forecasts, especially for those species capable of rapid spread.
Here we describe a model to predict the geographic spread of the hemlock woolly adelgid, HWA (Adelges tsugae Annand; Hemiptera: Adelgidae), an introduced forest pest that threatens eastern hemlock (Tsuga canadensis (L.) Carr.) and Carolina hemlock (Tsuga caroliniana Englemann) in eastern North America (Orwig et al. 2002). The model combines dynamic dispersal and population processes with fine-resolution maps characterizing spatiotemporal heterogeneity in climate and habitat in order to model range expansion across large, heterogeneous landscapes. We parameterize our model using field data sets on the population and spread dynamics of HWA, and we evaluate the predictions of the model against a 60-year record of HWA spread across eastern North America. These longterm empirical observations of spread provide a rare opportunity to evaluate how well dynamic spread models might anticipate range expansion. Although several studies have investigated the relationships between HWA spread and a variety of environmental factors (Koch et al. 2006, Evans and Gregoire 2007, Morin et al. 2009, Fitzpatrick et al. 2010), these studies have been limited either in geographic extent and/or by a coarse spatial resolution. Further, correlations between environmental parameters and hemlock abundance have hindered the ability of regression models to draw inferences regarding the processes influencing the spread of HWA (Morin et al. 2009). Specifically, our objectives are threefold: (1) parameterize a model using field data on population growth and historic spread patterns of HWA, (2) use this model to investigate range expansion of HWA across the range of hemlock, and (3) compare the simulated pattern of spread against the observed pattern. Of particular interest is how temporal and spatial heterogeneity in habitat suitability affect range expansion. In addition to providing taxon-specific information regarding HWA range expansion, our approach represents a general framework for developing dynamic spread models that explicitly incorporate environmental heterogeneity.

\section{Methods \\ Study system}

The hemlock woolly adelgid (HWA) is a small (1-mm adult), flightless insect (see Plate 1) native to Japan and China that was first collected from hemlock trees (Tsuga spp.) in the eastern United States in spring of 1951, in Richmond, Virginia (Stoetzel 2002). By 1969 HWA had spread to Philadelphia, Pennsylvania (G. Miller, personal communication), and to southern New England by 1985 (McClure 1990). The invaded range now stretches from Maine, New Hampshire, and Vermont in the north to Georgia in the south.

HWA is a bivoltine insect that has a holocyclic life cycle in its native range but is obligately parthenogenetic in its invaded range. The parthenogenetic nature of HWA in eastern North America means that even a single colonizing individual can start a new infestation; 
as a result, Allee effects at range margins are unlikely to affect spread dynamics (cf. Johnson et al. 2006). Adelgids have two generations per year composed of three life forms, the sistens (present from July to June), the progrediens (present from April to July), and the winged sexuparae (which emerge concurrently with the progrediens in spring). In Asia, the winged sexuparae fly to spruce and reproduce sexually. Because sexuparae do not survive on spruce species found in North America (McClure 1989), this actively mobile life stage does not play a role in the invasion of HWA, and acts as a population sink. Progrediens are sessile hemlock feeders that settle exclusively on foliage from the previous year's growth. They mature by June and give rise to the next generation of sistens. The sistens generation develops during autumn and winter, following a summer aestivation period. About $85 \%$ of sistens settle on new growth produced by the tree in spring (McClure 1991) and the remainder on older growth. In spring, the sistens produce eggs that develop into either progrediens or sexuparae, thereby completing the life cycle. Sistens tend to produce more numerous offspring than do progrediens (McClure 1989). Feeding progrediens and sistens do not move between branches, so the "crawler" nymphs (life stage between eggs and sessile adults) and potentially eggs are the sole dispersal stages in eastern North America. Dispersal is passive, with wind, birds, deer, and humans thought to act as the primary dispersal agents (McClure 1990). See McClure (1989, 1991) for additional details regarding the life cycle of HWA.

\section{General framework}

We develop a spatially explicit, discrete space-time stochastic model that links within-patch population dynamics and between-patch propagule dispersal with fine-resolution maps characterizing spatiotemporal variability in climate and hemlock abundance to simulate range expansion of HWA across the heterogeneous landscape of eastern North America. The model incorporates the influence of four heterogeneous factors on HWA spread: (1) hemlock abundance, (2) winter temperature, (3) population growth, and (4) dispersal. Hemlock abundance and winter temperature are characterized as raster maps composed of $1 \times 1 \mathrm{~km}$ cells (see Appendix A for details regarding the creation of these maps, which are available online from the Harvard Forest LTER data archive). ${ }^{6}$ It is across these maps that the model simulates HWA population growth and dispersal on an annual time step. Hemlock abundance in each cell (Fig. 1) determines the probability that dispersing adelgids establish in a location and also sets the upper limit to HWA population growth once a cell becomes infested. Hemlock abundance declines annually

${ }^{6}$ http://harvardforest.fas.harvard.edu/data/archive.html in infested cells and, for tractability, is assumed to remain constant elsewhere. Winter temperatures (Appendix C: Fig. C1), which change annually following observed temperature fluctuations, influence population growth by limiting the proportion of overwintering sistens that survive to produce progrediens in the next year. Mortality rates of progrediens (which include production of sexuparae, a demographic dead end) and sistens are drawn from appropriate probability distributions. Dispersal between cells is simulated using a function parameterized from multiple data sets documenting the spread of HWA across different regions of the eastern United States.

A single simulation of the model proceeds as follows. To initiate a simulation, a random number of HWA are introduced to a cell containing hemlock near Richmond, Virginia, the location of the first documented infestation of HWA in eastern North America (Stoetzel 2002). The simulation continues thereafter for 58 annual time steps, representing the period from 1951 (date of first HWA collection in the eastern United States) through 2008, with time steps beginning with production of progrediens in the spring by overwintering sistens and ending with winter mortality of sistens. First, sistens in infested cells that have survived the winter produce the next generation of progrediens crawlers, a portion of which disperse to neighboring cells either through local diffusion or via long-distance dispersal described using a distance-based probability density function. Dispersing individuals can (1) initiate new infestations in uninfested cells containing hemlock, (2) reestablish in the cell from which they originated, or (3) die if they fail to establish in a cell with hemlock or if they disperse to a cell without hemlock. The probability that dispersing individuals establish is equivalent to the fraction of the cell covered by hemlock crown and is therefore related to hemlock abundance. Carrying capacity of HWA populations is also determined by hemlock abundance; after dispersal, the surplus individuals larger than the carrying capacity of the cell die. The remaining population is then subjected to stochastic mortality. Surviving progrediens reproduce to create the next generation of sistens crawlers. Sistens follow the same cycle of dispersal, establishment, and mortality as progrediens, including limiting population size to carrying capacity, but with sistens being subjected to two additional forms of mortality: summer aestivation and overwintering. Hemlock abundance, and therefore carrying capacity and probability of establishment, declines each year in infested cells as a function of HWA population density. Stochasticity enters the model via random sampling from appropriate probability distributions that influence population growth and mortality, dispersal and establishment. These components are described in more detail in the next sections. The parameters of the model are summarized in Table 1. Simulations were constrained to the region of eastern 


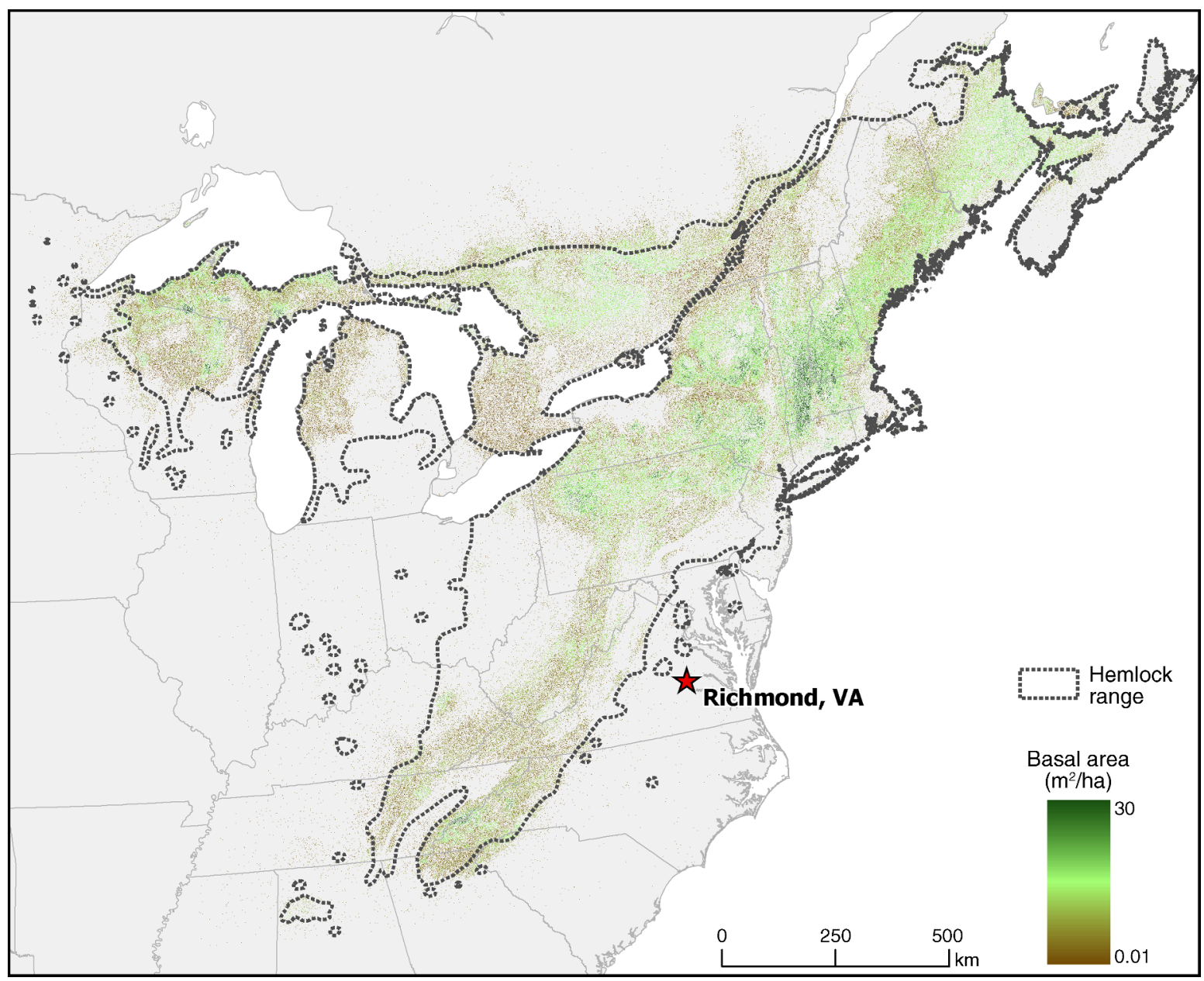

Fig. 1. Eastern North America showing modeled hemlock (Tsuga spp.) abundance, by basal area, at $1 \times 1 \mathrm{~km}$ resolution vs. the geographic range of hemlock (USGS 1999). The red star indicates the location of Richmond, Virginia (VA), where introduced populations of hemlock woolly adelgid (Adelges tsugae) were first collected in 1951.

North America encompassing the natural distribution of hemlock (Fig. 1). We used the results of the 1000 stochastic simulations to obtain an average representation of HWA spread. The model was written in the statistical language R (R Development Core Team 2009) and the code is available from the Supplement.

\section{Hemlock abundance}

We mapped geographic variation in hemlock abundance $\left(B_{i}\right)$ as basal area $\left(\mathrm{m}^{2}\right)$ in each $1 \times 1 \mathrm{~km}$ cell $i$ following the procedures described in Appendix A. The amount of hemlock in a cell determines both the number of HWA that the cell can support and the probability that dispersing HWA encounter hemlock. HWA attach themselves at the base of needles, typically at a rate of one individual per needle. Thus, the number of needles in a stand can serve as a reasonable estimate of the carry capacity of HWA populations. To estimate the number of needles in each stand, we used allometric relationships to compute leaf area from basal area (Kenefic and
Seymour 1999) and the number of needles $\left(L_{i}\right)$ from the mean leaf area per needle (Santee and Monk 1981). Because sistens feed predominantly on new growth, typically at a rate of $85 \%$ on new growth and $15 \%$ on older foliage (McClure 1991; A. Paradis and J. Elkinton, unpublished data), we used field surveys of uninfested hemlocks to estimate the proportion of total leaf area in new growth $\left(w_{i}\right)$. This quantity varied by tree size and site conditions, but we estimated it to be between $1 \%$ and $10 \%$. Together, these quantities allowed us to estimate the carrying capacity of progrediens $\left(K_{\mathrm{P} i}\right)$, which settle exclusively on the previous years' growth and therefore can be approximated as $K_{\mathrm{P} i}=L_{i}$, and the carrying capacity of sistens as $K_{\mathrm{S} i}=0.85 L_{i} w_{i}+0.15 L_{i}$. To estimate probability of establishment, we used allometric relationships to compute crown area $\left(C_{i}\right)$ in $\mathrm{m}^{2}$ from basal area (Santee and Monk 1981). We assumed the probability that dispersing HWA establish in a cell is equivalent to the ratio of $C_{i}$ to cell area in $\mathrm{m}^{2}$. Therefore, the number of HWA that establish in a cell is 
TABLE 1. Overview of default and fitted parameter values of the hemlock woolly adelgid (HWA) range expansion model.

\begin{tabular}{|c|c|c|c|}
\hline Symbol & Parameter & Type & $\begin{array}{l}\text { Value, range, } \\
\text { or distribution }\end{array}$ \\
\hline \multicolumn{4}{|l|}{ General } \\
\hline$i$ & Index of a particular cell & index & $\ldots$ \\
\hline$j$ & Index of a particular year & index & $1951-2008$ \\
\hline \multicolumn{4}{|c|}{ Population dynamics } \\
\hline$N_{0}$ & Initial population size in Richmond, Virginia in 1951 & random & $\sim$ Poisson(1000) \\
\hline$K_{\text {Pit }}$ & Carrying capacity of progrediens in cell $i$ in year $t$, equal to $L_{i t}$ & modeled & $\cdots$ \\
\hline$K_{\mathrm{S} i t}$ & $\begin{array}{l}\text { Carrying capacity of sistens in cell } i \text { in year } t \text {, function of } L_{i t} \\
\text { and } \mathrm{w}_{i t}\end{array}$ & modeled & $\cdots$ \\
\hline$N_{\text {P } i t}$ & Progrediens population size in cell $i$ in year $t$ & modeled & {$\left[0, K_{\mathrm{P} i t}\right]$} \\
\hline$N_{\text {Sit }}$ & Sistens population size in cell $i$ in year $t$ & modeled & {$\left[0, K_{\text {Sit }}\right]$} \\
\hline$W_{i t}$ & Winter temperature in cell $i$ in year $t$ & observed & \\
\hline$P_{i t}$ & Number of progrediens produced by each sisten in cell $i$ in year $t$ & random & $\sim$ Poisson(142.7) \\
\hline$S_{i t}$ & Number of sistens produced by each progredien in cell $i$ in year $t$ & random & $\sim$ Poisson(22.2) \\
\hline$M_{\mathrm{P} i t}$ & Mortality rate of established progrediens in cell $i$ in year $t$ & random & $\sim \operatorname{Binomial}(0.98)$ \\
\hline$M_{\text {Sit }}$ & Mortality rate of established sistens in cell $i$ in year $t$ & random & $\sim \operatorname{Binomial}(0.64)$ \\
\hline$M_{\text {Sa } i t}$ & Mortality rates of sistens during aestivation in cell $i$ in year $t$ & random & $\sim \operatorname{Binomial}(0.71)$ \\
\hline$M_{\text {Swit }}$ & $\begin{array}{l}\text { Overwintering mortality rate of sistens in cell } i \text { in year } t \text {, function } \\
\text { of } W_{i t}\end{array}$ & modeled & {$[0,1]$} \\
\hline \multicolumn{4}{|c|}{ Host dynamics } \\
\hline$B_{i t}$ & Basal area of hemlock in cell $i$ year $t$ & modeled & $\cdots$ \\
\hline$L_{i t}$ & Leaf area in cell $i$ in year $t$, function of $B_{i t}$ & modeled & .. \\
\hline$C_{i t}$ & Crown area in cell $i$ in year $t$, function of $B_{i t}$ & modeled & ‥ \\
\hline$\omega_{i t}$ & Proportion of $L_{i t}$ that is new growth & random & $\sim$ Uniform $(0.01,0.05)$ \\
\hline \multicolumn{4}{|c|}{ Dispersal dynamics } \\
\hline$\mu$ & Mean of the log-normal dispersal pdf & modeled & $4.73 \mathrm{~km}$ \\
\hline$\sigma$ & Standard deviation of the log-normal dispersal pdf & modeled & $3.27 \mathrm{~km}$ \\
\hline$\phi_{i t}$ & $\begin{array}{l}\text { Proportion of individuals diffusing to adjacent cells in cell } i \text { in } \\
\text { year } t\end{array}$ & random & $\sim \operatorname{Uniform}\left(0,1 \times 10^{-6}\right)$ \\
\hline$\gamma_{i t}$ & Proportion of long-distance dispersers in cell $i$ in year $t$ & random & $\sim$ Uniform $\left(0,1 \times 10^{-8}\right)$ \\
\hline
\end{tabular}

simply $C_{i}$ multiplied by the number of HWA dispersing to that location. In infested cells, temporal variation in hemlock abundance in each year $t$ was introduced by reducing hemlock abundance as a function of HWA population density, thereby also reducing carry capacity and probability of establishment in the next year. See Appendix B for a description of how hemlock decline was estimated. For tractability, hemlock abundance was assumed to remain constant in uninfested cells throughout the simulation.

\section{Winter temperature}

Of the causes of HWA mortality, winter temperatures are thought to be the most important and most variable in space. The relationship between HWA mortality and temperature has been assessed in both the laboratory and the field (Parker et al. 1999, Skinner et al. 2003, Shields and Cheah 2005, Paradis et al. 2008, Trotter and Shields 2009). Winter temperatures can cause considerable mortality and trigger dramatic population declines, with southern populations typically experiencing significantly less mortality than those in the north (Shields and Cheah 2005, Trotter and Shields 2009).

Paradis et al. (2008) explored the relationship between winter temperature and HWA overwintering mortality and determined that of eight different measures of winter temperature they considered, average daily mean winter (December-March) temperature had the greatest explanatory power. To account for the geographic variability in HWA winter mortality, we used the bestfit regression equation from Paradis et al. (2008) to express overwintering mortality $\left(M_{\mathrm{S} w i t}\right)$ in cell $i$ in year $t$ as a function of temperature $\left(W_{i t},{ }^{\circ} \mathrm{C}\right): M_{\text {Swit }}=0.507-$ $0.078 W_{i t}$. To incorporate stochasticity in $M_{\text {Swit }}$, we used values for the slope and intercept drawn from the $95 \%$ confidence intervals reported by Paradis et al. (2008). See Appendix $\mathrm{C}$ for details regarding the creation of annual mean winter temperature maps.

\section{Within-cell population dynamics}

We used multiyear surveys of HWA reproduction and survival rates in Massachusetts and Connecticut to estimate mean values of parameters for the life stages of HWA. See Appendix D for details regarding how these data were collected. Using these data, we estimated probability distributions that were sampled to estimate stochastic reproduction and mortality of the sistens and progrediens generations in each cell $i$ in year $t$. For the progrediens generation, these parameters included average number of progrediens produced by each overwintering sistens $\left(P_{i t}\right)$ and the mortality rate of progrediens $\left(M_{\mathrm{P} i t}\right)$. For the sistens generation, parameters included the average number of sistens produced by progrediens $\left(S_{i t}\right)$ and the mortality rates of dispersing, aestivating, 
and overwintering sistens $\left(M_{\mathrm{S} i t}, M_{\mathrm{S} a i t}, M_{\mathrm{S} w i t}\right.$, respectively, with $M_{\text {Swit }}$ calculated as described in the previous section). To model stochastic population growth, we sampled Poisson distributions with means $P_{i t}$ or $S_{i t}$ and multiplied these values by the existing population size of either sistens $\left(N_{\mathrm{S} i t}\right)$ or progrediens $\left(N_{\mathrm{P} i t}\right)$. Binomial distributions with means $M_{\mathrm{P} i t}, M_{\mathrm{S} i t}$, or $M_{\mathrm{S} a i t}$ were used to model mortality of progrediens and sistens. We incorporated the influence of density dependence on population dynamics by allowing HWA density to increase to the carry capacity set by hemlock abundance as described previously and by reducing hemlock abundance in infested cells as described in Appendix B.

\section{Between-stand dispersal}

Range expansion of organisms is often driven by multiple mechanisms that operate at different scales (Higgins et al. 2003, Hastings et al. 2005), a process termed stratified dispersal (Hengeveld 1988). The biology and historic pattern of spread of HWA is consistent with this form of dispersal. Dispersal within hemlock stands is facilitated by progrediens and sistens nymphs crawling along branches or between proximate trees, whereas wind, birds, humans, or other agents facilitate rare long-distance dispersal between stands (McClure 1990). Our model characterized stratified dispersal by allowing local diffusion between neighboring cells and by using historic data on HWA spread to fit a function that models long-distance dispersal events.

To fit a function representing the frequency distribution of between-stand dispersal distances, hereafter termed the distance-based probability density function or "distance-pdf," we used multiple data sets describing the historic spread of HWA (Table 2). Note that a distance-pdf differs from a dispersal kernel, which describes the density of propagules as a function of the distance from a source (Cousens et al. 2008). The data sets describing spread varied in their geographic focus and their spatial and temporal coverage (Table 2), but all represent either purposeful or ad hoc surveys of regionally distributed hemlock stands rather than trees within stands, and therefore represent a sample of successful between-stand dispersal events. Appendix E describes how these data were fit to a set of candidate distance-pdfs using maximum likelihood. Given their coarse spatial resolution, we did not use the existing USFS county-level spread data set to inform the distance-pdf. These data were, however, used in model evaluation (USFS data available online). ${ }^{7}$

For both between-cell and long-distance movements, it was assumed that a small fraction of $N_{\mathrm{S} i t}$ (population size of sistens) and $N_{\text {Pit }}$ (population size of progrediens) was subject to dispersal. These proportions of dispersing individuals were drawn from different uniform probability distributions for local diffusion $\left(\phi_{i t}\right)$ and long-

${ }^{7}$ http://na.fs.fed.us/fhp/hwa/maps/distribution.shtm
TABLE 2. Data sets describing the spread of hemlock woolly adelgid at the landscape scale that were used to parameterize the dispersal probability density function.

\begin{tabular}{lcc}
\hline \hline \multicolumn{1}{c}{ Region } & $\begin{array}{c}\text { No. } \\
\text { locations }\end{array}$ & $\begin{array}{c}\text { Year of first/ } \\
\text { last observation }\end{array}$ \\
\hline Georgia & 1057 & $2003 / 2006$ \\
Southwestern Virginia & 98 & $1997 / 2007$ \\
Pennsylvania & 1598 & $1982 / 2006$ \\
Connecticut and Massachusetts $\dagger$ & 142 & $1998 / 2007$ \\
New Hampshire & 73 & $2000 / 2008$ \\
\hline
\end{tabular}

Notes: See Acknowledgments for data sources.

$\dagger$ Preisser et al. (2008).

distance dispersal $\left(\gamma_{i t}\right)$ and were multiplied by $N_{\mathrm{S} i t}$ and $N_{\text {Pit }}$ to calculate the number of dispersing HWA in each generation. Ideally these proportions could be estimated using maximum likelihood approaches, but the data necessary to fit such a likelihood function currently are not available for HWA. To estimate the proportions of dispersing individuals, we therefore performed a sensitivity analysis that confirmed that spread rate was indeed sensitive to these parameters and that reasonable results (spread rate of $\sim 10-20 \mathrm{~km}$ per year; Evans and Gregoire 2007) were obtained if we assumed that one individual in a million diffused to neighboring cells and if one individual in 100 million was subjected to longdistance dispersal as described by the distance-pdf.

\section{Model evaluation}

We evaluated predictive performance of the model in two ways. First, to assess spatial accuracy, we used the area under the curve (AUC) of the receiver operating characteristics curve (ROC; Fielding and Bell 1997) to compare the predicted probability of infestation with the observed spatial pattern of HWA infestations in three locations: the northern extent of the range in New England, near the center of the range in Pennsylvania, and the southern extent of the range in Georgia. Second, to assess temporal accuracy, we compared the predicted timing of first infestation to the observed year of infestation using the 60-year record of spread from the USFS county-level data set. We used the following procedure to address the scale mismatch between the model $\left(1-\mathrm{km}^{2}\right.$ cells) and the observation data (county level, $>10^{3} \mathrm{~km}^{2}$ ). Given the size of counties, each contained numerous cells. Each cell within a county had a predicted year of first infestation for each of the 1000 simulations. For each county, we obtained the predicted years of first infestation across all cells within the county and across all 1000 simulations. Cells that did not become infested were ignored. Thus, if a county had 100 cells, all of which were infested in all 1000 simulations, we obtained a distribution of predicted years of infestation for the county composed of $1 \times 10^{5}$ data points. To evaluate the extent to which the predicted dates of infestation compared to the observed date, we determined whether the $95 \%$ confidence interval of the distribution of predicted years contained the observed year. 


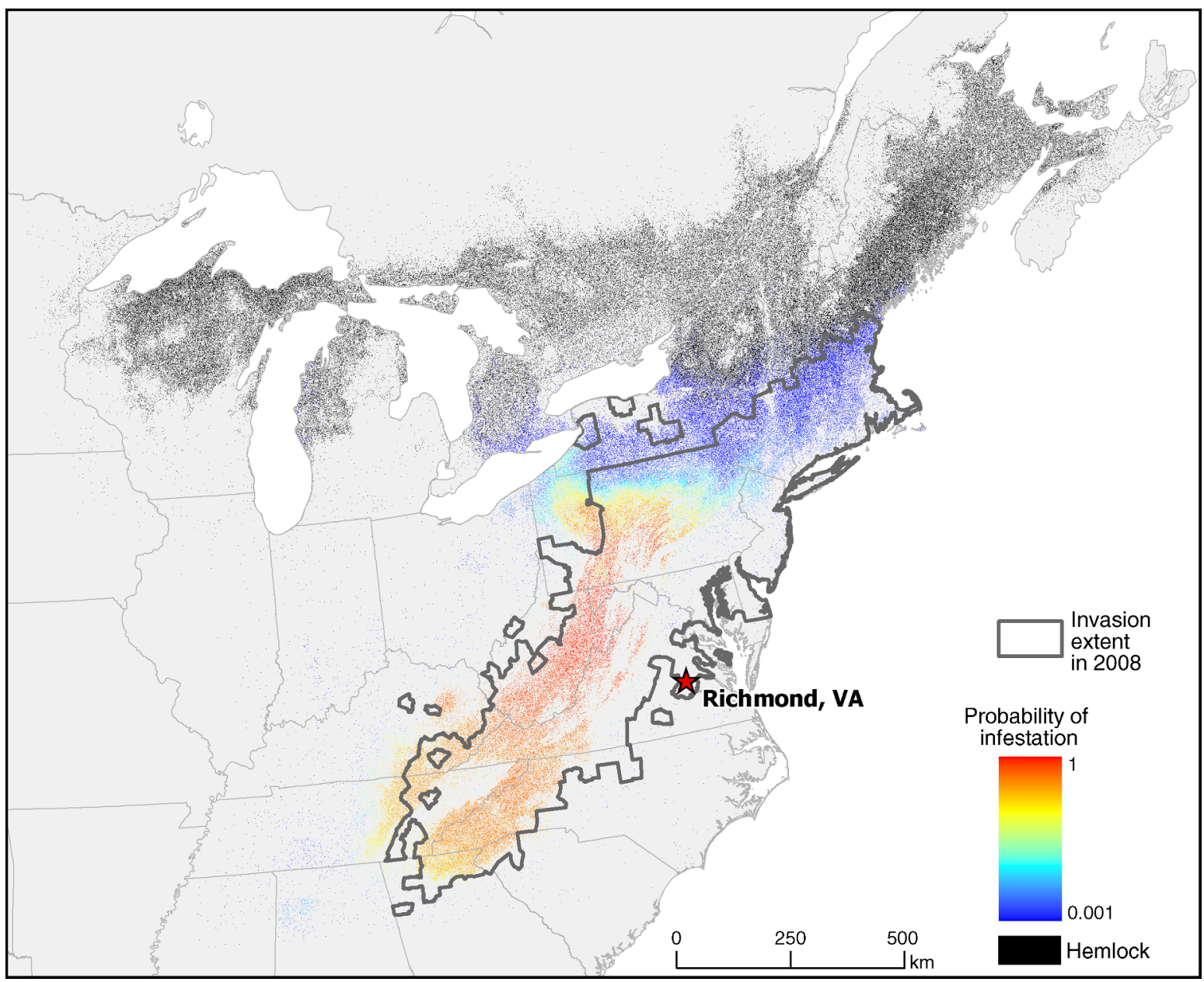

FIG. 2. Predicted probability of infestation of hemlock stands by hemlock woolly adelgid averaged over 1000 simulations of range expansion initiated in Richmond, Virginia, using annual winter temperatures experienced during the period 1951-2008. The observed extent of the invasion in 2008 is delineated by the bold gray line. Hemlock stands not predicted to become infested in any of the 1000 simulations are shown in black. Light-gray regions do not contain hemlock.

\section{RESULTS}

The maximum-likelihood estimation of the distancepdf determined that a log-normal function with a dispersal distance of $4.73 \mathrm{~km}$ [4.5-5.0 km] (mean and $95 \% \mathrm{CI}$ ) provided the most plausible fit to the observed HWA spread data (Appendix E: Fig. E1). Application of the model to spatially and temporally heterogeneous hemlock abundance (Fig. 1) and mean winter temperature (Appendix C: Fig. C1) over the 57-year simulation period suggested that the probability of infestation was greatest from central Pennsylvania to the southernmost extent of the geographic range of hemlock in northern Georgia (red-yellow shading, Fig. 2; see Appendix F: Fig. F1 for an animated version of this figure). Regions of southern New York and New England, portions of which currently are infested by HWA, were generally predicted to have very low probabilities $(<1 \%)$ of invasion (blue shading, Fig. 2), whereas most of northern New England, Wisconsin, the upper peninsula of Michigan, and southern Canada had zero probability of infestation. In the southern portion of the study region, probabilities of infestation generally increased with time before gradually declining as hemlock was lost from the region (Appendix F: Fig. F1, animated). In contrast, probabilities of infestation did not increase above zero in southern New England until late in the simulation, where invasion risk tended to remain low and fluctuate yearly in response to year-to-year changes in winter temperature. Geographic and temporal variation in HWA population size tended to follow the pattern of probability of infestation, with population sizes being greatest south of central Pennsylvania and remaining relatively small in the north (Appendix G: Fig. G1, animated).

Earliest infestations were concentrated in the central Appalachians, with subsequent spread to the south and followed by later spread to the north (Fig. 3). In general, HWA was not predicted to arrive in northern Pennsylva- 


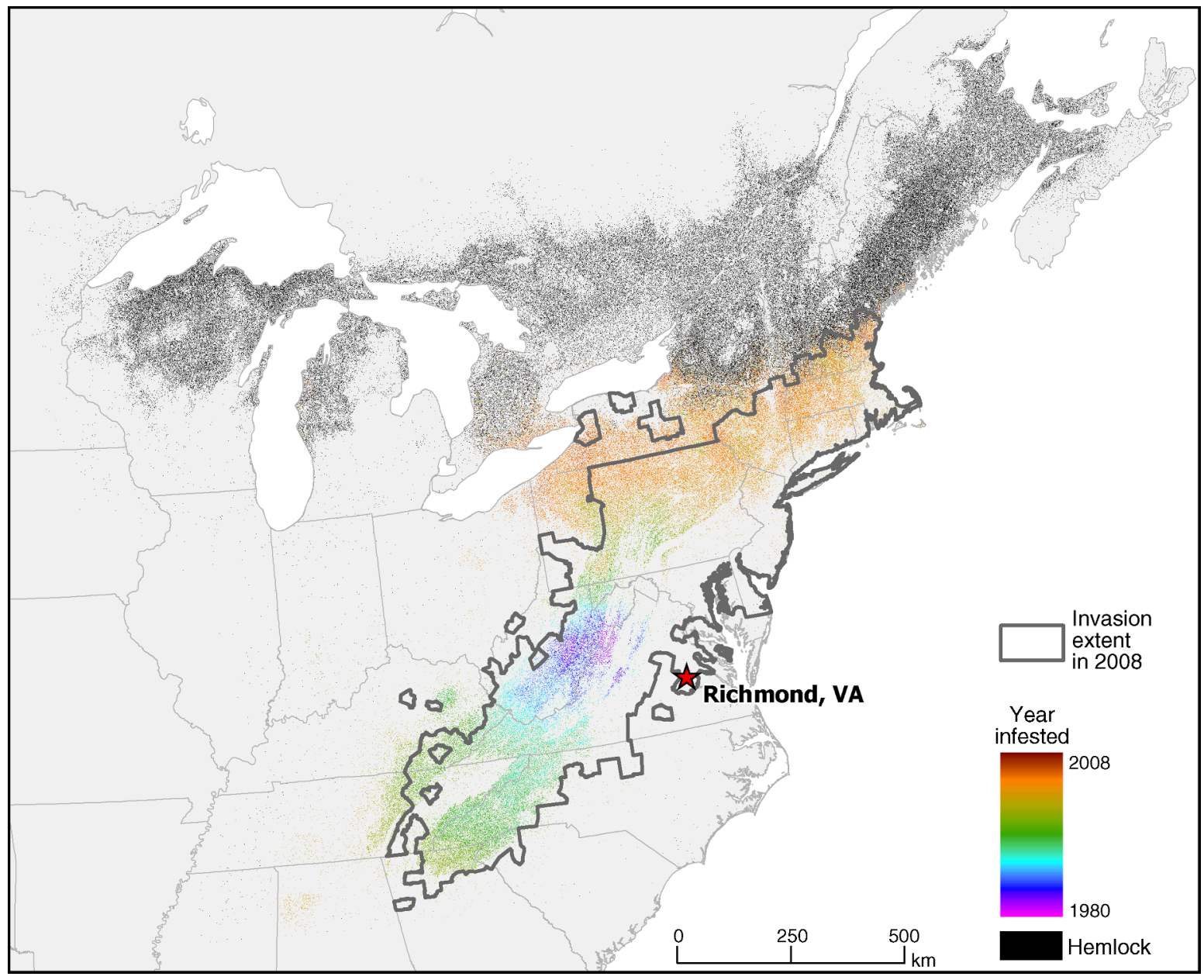

FIG. 3. Predicted year of infestation of hemlock stands by hemlock woolly adelgid averaged over 1000 simulations of range expansion initiated in Richmond, Virginia, using annual winter temperatures experienced during the period 1951-2008. The observed extent of the invasion in 2008 is delineated by the bold gray line. Hemlock stands not predicted to become infested in any of the 1000 simulations are shown in black. Light-gray regions do not contain hemlock.

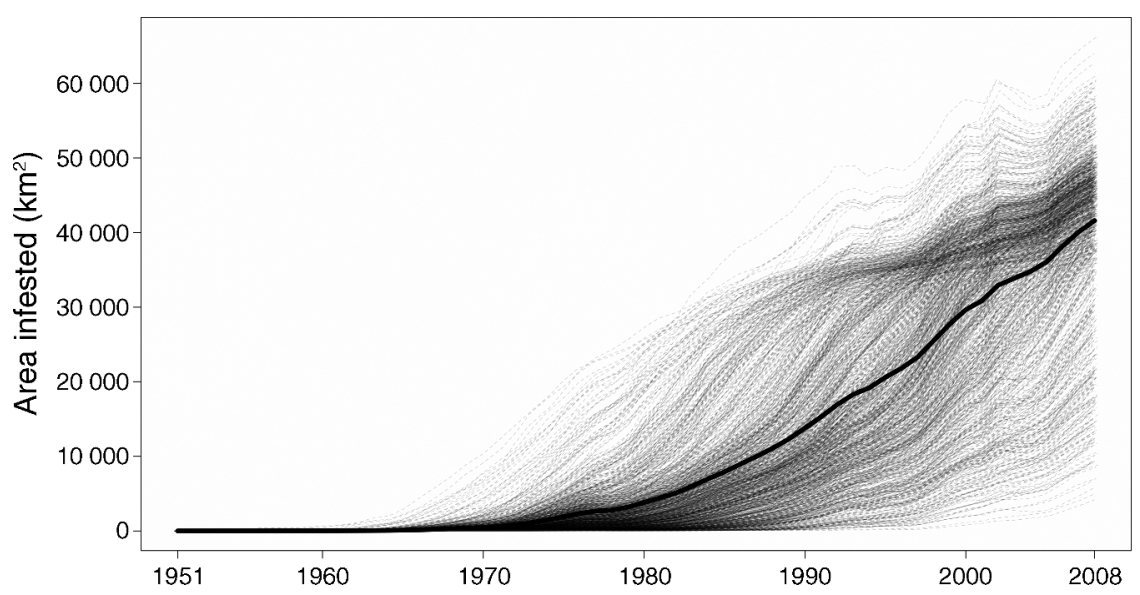

FIG. 4. Total area infested vs. time for each of the 1000 individual simulations (dashed gray lines) and the mean (solid black line) total area infested. 


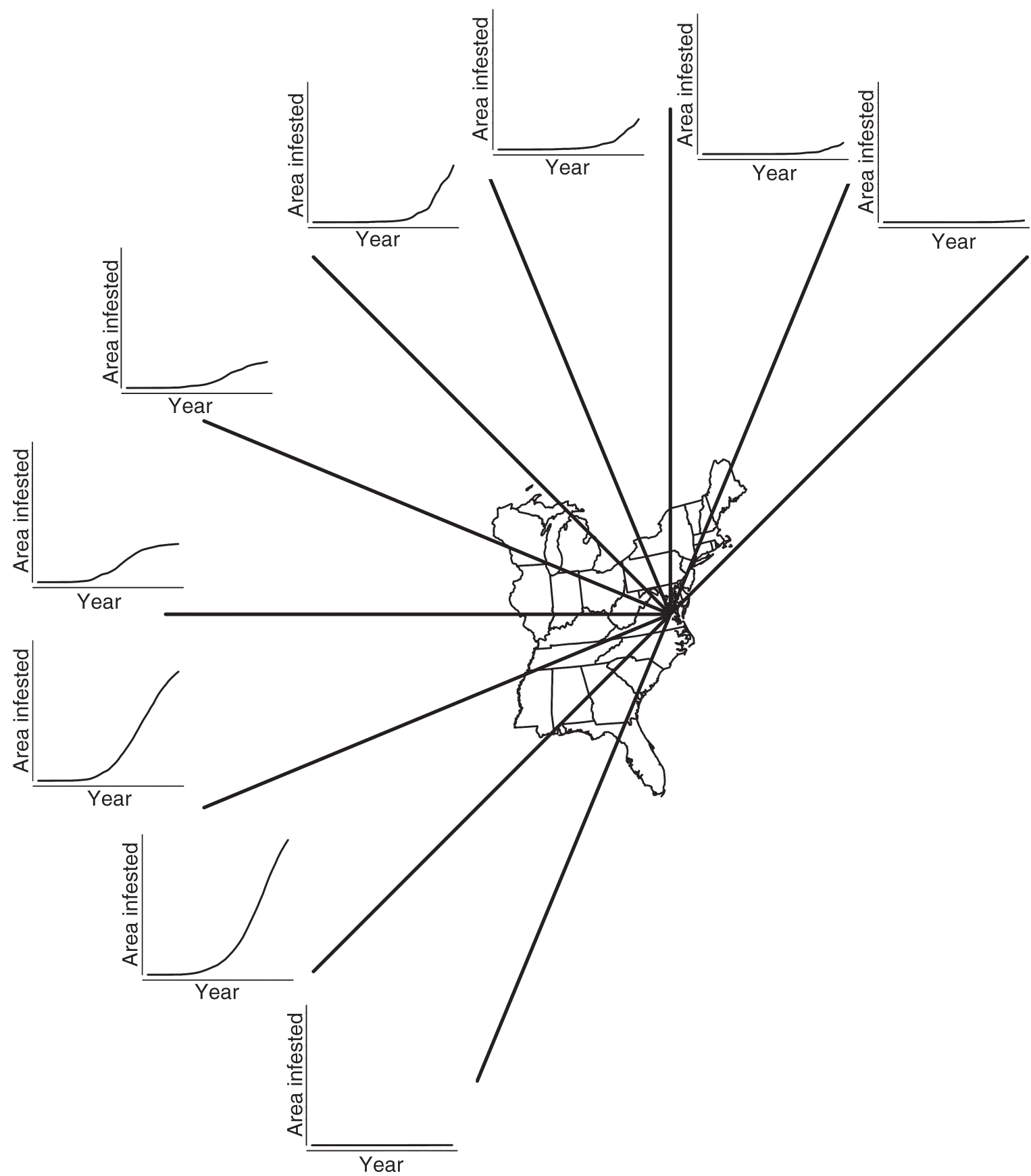

FIG. 5. Area of hemlock infested $\left(\mathrm{km}^{2}\right)$ vs. year (1951-2008) averaged over 1000 simulations within different geographic regions defined by dividing the study area into $22.5^{\circ}$ intervals (16 cardinal directions), using Richmond, Virginia, as the origin. The $y$-axis scales are the same for each region. The rate of spread, indicated by the slope of the line in each panel, is most rapid in the southwest and slowest in the northeast.

nia and southern New England until after year 2000. On average, the model predicted an overall increase in infested area beginning around 1970 and continuing to increase throughout the simulation period (Fig. 4). Simulated spread was most rapid in the southwest and was slowest in the north and northeast (slopes of curves, Fig. 5).
The spatial accuracy of the model measured using AUC varied by geographic region (Fig. 6). AUC was highest in New England (NE, solid line; Fig. 6) and Georgia (GA, dashed line; Fig. 6), where the model had excellent to good discrimination (Pearce and Ferrier 2000). In contrast, model performance was poor (less 
than 0.5) in Pennsylvania (PA, dotted line; Fig. 6), where the model over-predicted the observed extent of the invasion in the northwestern portion of the state.

Of the 325 counties that were known to be infested by HWA in 2008, the observed year of first infestation fell within the $95 \%$ confidence interval of the simulated year for only 37 counties (11.4\%) (Fig. 7, hatched counties). There was no discernable geographic patterning to these 37 counties, which tended to be scattered throughout the study area. In contrast, there were strong geographic patterns in model error. In general, the model predicted arrival later than observed (Fig. 7, purple shading) in the north and earlier than observed (Fig. 7, green shading) in the south. In some instances the difference between the observed and modeled year of first infestation differed by more than 15 years. Most notably, HWA was predicted to arrive much later than observed in counties surrounding New York, New York and the city of Philadelphia, Pennsylvania. In addition, there were 13 known-infested counties that the model did not predict would become infested (Fig. 7, black-shaded counties). These areas included Philadelphia County, Pennsylvania as well as counties containing New York, New York.

\section{DisCUSSION}

The objectives of this study were to develop a processbased, stochastic model to simulate range expansion of HWA across the large heterogeneous landscape of eastern North America, to examine how environmental heterogeneity affected spread dynamics, and to compare the predictions of the model with the observed pattern of range expansion. Taken together, our model predicts considerable heterogeneity in the risk of HWA invasion across space and through time, with spatiotemporal variation in winter temperature, rather than hemlock abundance, exerting a primary control on simulated spread dynamics. The simulated dynamics match some aspects of the observed pattern of range expansion, most notably the extent of invasion and anisotropic spread, but our model did not correctly predict the timing of HWA's arrival in different geographic regions.

Ours joins a growing list of range expansion models that integrate temporal and spatial heterogeneity in habitat suitability with dynamic population and dispersal processes (Dullinger et al. 2004, Keith et al. 2008, Anderson et al. 2009, Meentemeyer et al. 2011). However, evaluations of dynamic models against longterm records of observed spread histories remain rare (but see Pitt et al. 2009) and such comparisons are sorely needed to quantify the extent to which dynamic models might anticipate rapid range expansion. HWA provides a particularly good study system because its population dynamics are strongly influenced by temperature and it is limited to discrete habitat patches of its host plant (hemlock). Most importantly in the context of model evaluation, the introduction and spread history of HWA are relatively well known. Therefore we have a unique opportunity to ask: Given what we know today, how

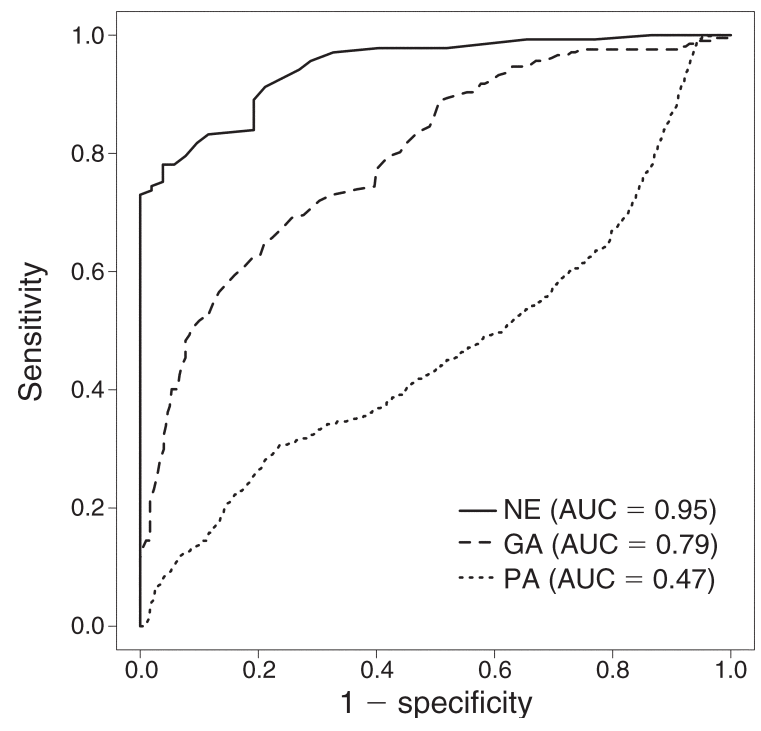

FIG. 6. Receiver operating characteristics (ROC) curves showing model performance in three geographic regions, including New England (NE), Georgia (GA), and Pennsylvania (PA). Higher values for AUC (area under the curve) indicate greater spatial accuracy of the model.

well could we have anticipated the spread of HWA across eastern North America? This question can be considered in the context of (1) extent of infestation, (2) rate of spread, and (3) timing of arrival.

In terms of extent of invasion, our simulations generally agree with the observed current extent of HWA's spread (Figs. 2 and 6) and suggest that there are few remaining opportunities for widespread invasion of HWA. The model suggests that lethal winter temperatures are likely to limit additional northward spread of HWA beyond its current northern limit. Northwestern Pennsylvania and southern New York represent notable exceptions, although invasion risks are rather low or zero across most of New York. Elsewhere, the invasion largely has already reached the extent of its potential range as determined by availability of hemlock.

The model predicted anisotropic spread (Fig. 5), generally matching the observed pattern of most rapid spread in the south and lower rates of spread elsewhere (Fitzpatrick et al. 2010). Our model predicted HWA to spread most rapidly across the southern Appalachians, where winters are relatively warm and hemlock is relatively abundant. Despite an abundance of hemlock in New England, HWA was predicted to spread slowly in this region, highlighting the importance of winter temperatures in limiting range expansion. It is worth noting that our findings contrast with regression-based analyses of the observed pattern of anisotropy, which suggest that, although spread rates of HWA were relatively rapid in the south, they were greatest in the northeast (Morin et al. 2009). However, this finding may in part be an artifact of the regression approach implemented by Morin et al. (2009), which assumes 


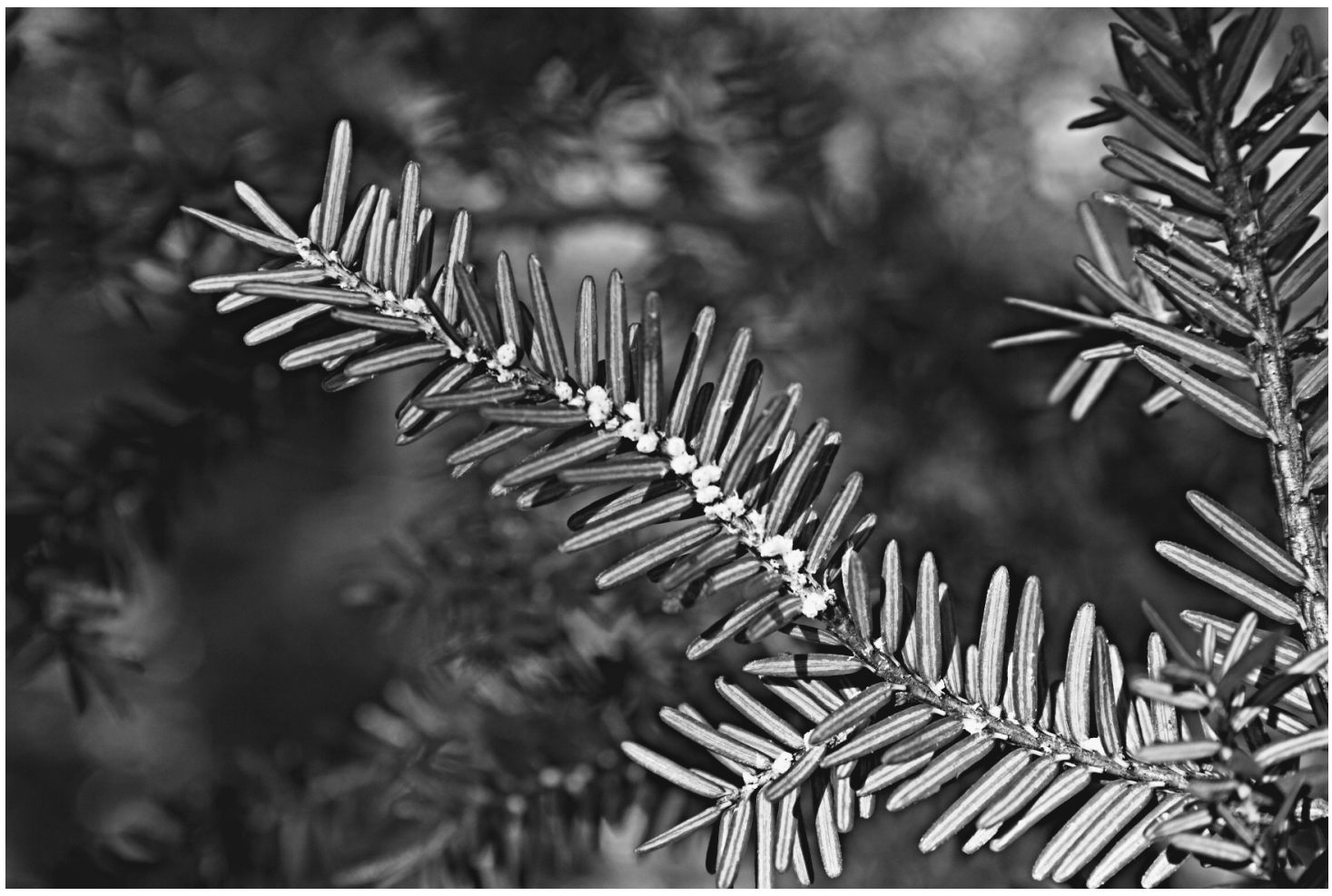

Plate 1. An overwintering population of invasive hemlock woolly adelgid (Adelges tsugae) on an isolated eastern hemlock (Tsuga canadensis) in the Buchanan State Forest near Beans Cove, Pennsylvania, USA. Each white, woolly mass contains a single individual of the sistens generation. By spring, individuals that have survived the winter could produce more than 100 eggs, each of which could hatch into nymphs capable of dispersing near and far. Photo credit: M. C. Fitzpatrick.

that spread rates are constant, and therefore can overestimate spread rates if long-distance dispersal events to a particular region are followed by slower diffusion (i.e., if invasion speed varies in time). This is the case with the dispersal of HWA to the northeast, which was facilitated by early, long-distance dispersal, followed by much slower rates of diffusion (Fitzpatrick et al. 2010).

Despite generally matching the observed extent of the invasion of HWA and the pattern of anisotropic spread, our model did a poor job of predicting the timing of arrival: a failure that we attribute to an inability of the model to adequately capture both the timing and direction of early, rare, long-distance dispersal events. Much has been written regarding the inherent difficulties of accurately measuring and modeling infrequent long-distance dispersal events and of the importance of such rare events in determining spread rate and ultimately timing of arrival of an organism undergoing range expansion (e.g., Clark et al. 1998, Higgins and Richardson 1999, Clark et al. 2001, Clark et al. 2003, Skarpaas and Shea 2007). For the most part, discussions regarding the modeling of long-distance dispersal have been one-dimensional in that they mainly have considered the shape of the probability function describing the distribution of dispersal distances. A less appreciated aspect of modeling range expansion is that, for models to be successful, they must also accurately model dispersal direction (i.e., anisotropy). In the case of HWA, data suggest that populations spread from Richmond, Virginia to Philadelphia, Pennsylvania then eventually to New York, New York. These early, longdistance movements to densely populated regions of the northeast were not captured in our simulations (black shading; Fig. 7), which may explain why the simulations predicted later arrival in the northeast than was observed. In fact, none of our simulations predicted that Philadelphia County, Pennsylvania and the counties surrounding New York, New York would become infested. These findings can be attributed in part to the failure of our hemlock map to capture urban hemlock density. Of equal or greater importance could be the role of long-distance dispersal vectors that increase the likelihood of spread to the east and northeast, most notable of which are wind and birds (McClure 1990). Dispersing progrediens hatch during the time of spring bird migration from south to north, and McClure (1990) found HWA attached to forest birds. Bird migration may be a particularly important dispersal vector in unforested areas such as cities, because isolated hemlocks probably have much higher bird visitation rates per tree than trees embedded in a forest. During the time of both progrediens and sistens dispersal, dominant winds are mainly out of the west 


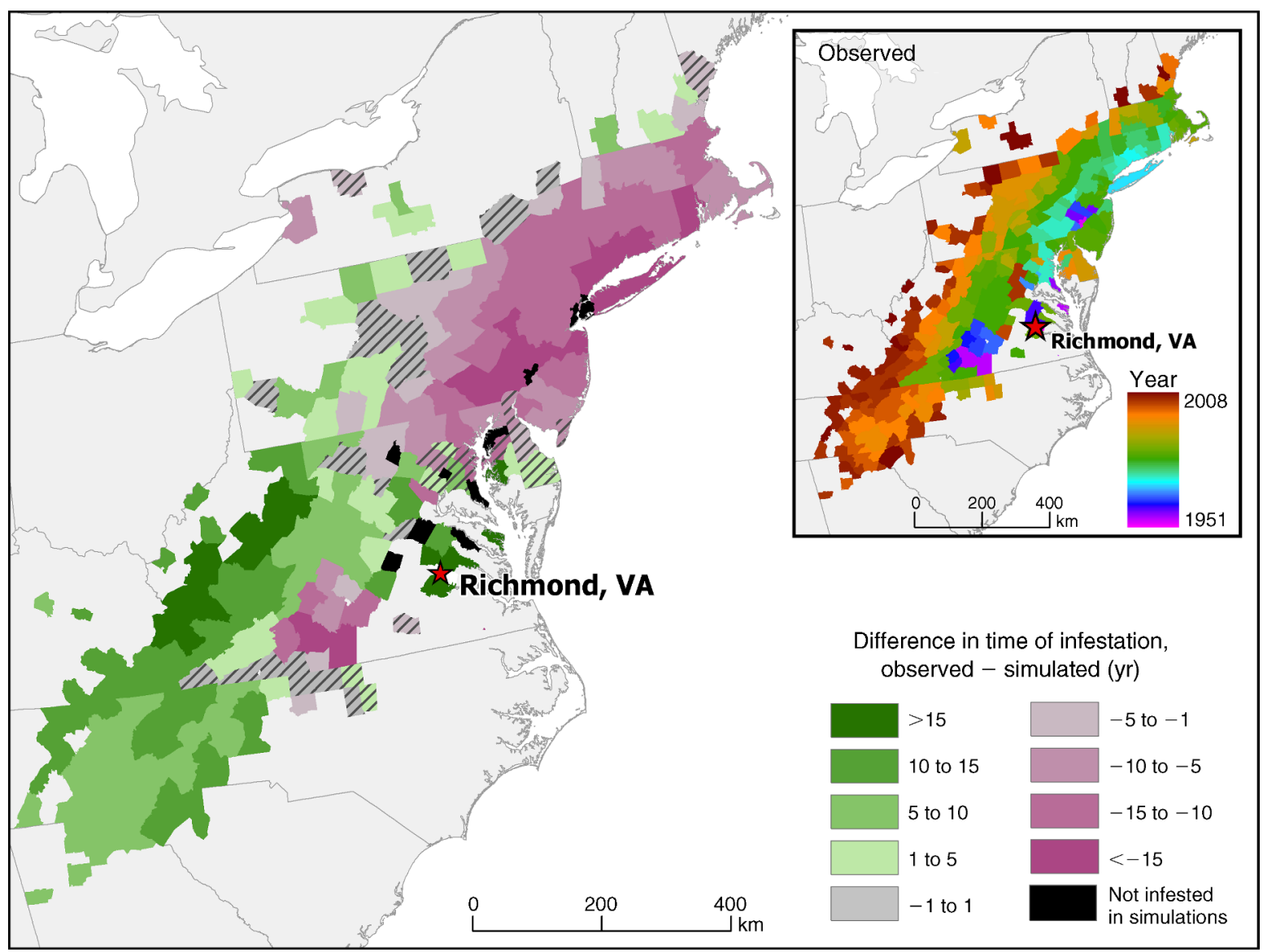

FIG. 7. Map of the difference between the observed (inset) and mean simulated year of infestation for counties infested by the hemlock woolly adelgid up to year 2008. Green/purple shading indicates counties for which the model predicted a county to become infested earlier/later than was observed. Gray shading indicates counties for which the simulated data fell within one year of the observed date. Hatching highlights those counties for which the observed year of infestation fell within the $95 \%$ confidence interval of the simulated year. Black shading represents counties where HWA has been observed but none of the 1000 simulations predicted infestation.

and southwest (Klink 1999). Consistent with the observed pattern of range expansion of HWA, the dominant winds and bird migrations would tend to reduce the probability of spread to the south and west, thereby delaying arrival in the southern Appalachians, while increasing spread potential to north and east. The failure to incorporate wind patterns may also explain why the model predicted a high probability of spread to upwind portions of northwestern Pennsylvania that are not currently known to be invaded (B. Regester, personal communication). The movement of hemlock for landscaping purposes may also play a role in facilitating long-distance dispersal of HWA, although the directionality of such movements is less clear. Taken together, the inability of the model to reproduce the observed timing of arrival in different regions seems to result largely from an inability to capture early dispersal events to northeastern cities and an overestimation of the frequency of long-distance dispersal events to the south and west.

Although the model failed to capture aspects of the spread of HWA, it is reasonable to ask: Within the context of the model, how likely was the observed pattern of spread? Invasion dynamics are dependent on a number of highly stochastic processes that pose major challenges to developing realistic models of range expansion. Vagaries of population dynamics and dispersal, particularly at early stages of range expansion (Higgins and Richardson 1999), can play a disproportionate role in determining the ensuing pattern of spread. It is reasonable to assume that small changes to any of these early dynamics could result in strikingly different patterns of range expansion. More broadly, the ecological patterns that we observe, and on which models are parameterized, represent a single realization of a multitude of possible realizations, some more likely than others. It is critical to note that although running 
many simulations can reduce the influence of model stochasticity on the predicted outcome, as well as provide an indication of uncertainty, model averaging may not necessarily bring us any closer to predicting the observed pattern. In fact, it could do just the opposite because averaging multiple simulations reduces the influence of uncommon, but highly consequential, events.

Knowledge of when and where an invasive species is likely to spread is critical to management efforts. In the case of HWA, there appears to be little potential for additional spread, at least under current climatic conditions, and therefore correspondingly small remaining opportunities for management intervention at the landscape scale. However, given the limiting effects of temperature on HWA range dynamics in New England, increases in winter temperature in this region could lead to the rapid spread of HWA (Paradis et al. 2008) and subsequent loss of hemlock. Planned applications of our model to scenarios of future climate in the northeastern United States and southern Canada will explore these dynamics in greater detail.

As global change continues to alter the distributions of native and exotic species, there is an increasing need for spatially explicit forecasts of range expansion. Here, we combined existing techniques for modeling population growth and dispersal with fine-resolution maps characterizing spatial and temporal variability in climatic and habitat suitability to model species spread over a large heterogeneous region. Ours is the sort of integrated model recently envisioned by Huntley et al. (2010), who, like many others, have argued that dynamic models are needed to provide more realistic forecasts of changes in species distributions, such as species responses to climatic change. Validation remains a central challenge however, as it is not possible to validate predictions of events that may not occur for decades. In contrast, invasive species offer a unique opportunity to observe range expansion over relatively short timescales and can therefore serve as a means to assess dynamic models of range expansion. Our results suggest that, by some measures, dynamic models can provide useful predictions of changes in species distributions in space broadly consistent with observed patterns. However, in instances where range expansion is driven by rare events with large consequences, for models to be successful in predicting timing of arrival, they must incorporate an improved understanding of the drivers of anisotropy. In the context of the range dynamics of HWA, this would include the role of passive dispersal vectors in driving long-distance dispersal events to cities in the northeastern United States and preventing spread to highly suitable locations elsewhere.

\section{ACKNOWLEDGMENTS}

This work would not have been possible without contributions from Annie Paradis. We also thank C. Burnham (Massachusetts), B. Burns (Vermont), J. Denham (New York), J. Johnson (Georgia), T. McAvoy (Virginia), G. Miller
(Smithsonian), D. Orwig (Connecticut/Massachusetts), and B. Regester (Pennsylvania) for kindly providing local HWA spread records. Geoff Boettner, Dave Mausel, and Artemis Roehrig contributed knowledge and field assistance. This research was funded by NSF DEB-0715504 to E. Preisser and by funding from UMCES-AL to M. C. Fitzpatrick. Comments from J. Ferrari, S. Liebhold, T. Trotter, and two anonymous reviewers greatly improved an early draft of the manuscript. This is UMCES Appalachian Laboratory Scientific Contribution No. 4572.

\section{Literature Cited}

Anderson, B., H. Akçakaya, M. Araújo, D. Fordham, E. Martinez-Meyer, W. Thuiller, and B. Brook. 2009. Dynamics of range margins for metapopulations under climate change. Proceedings of the Royal Society B 276:1415-1420.

Broennimann, O., U. A. Treier, H. Muller-Scharer, W. Thuiller, A. T. Peterson, and A. Guisan. 2007. Evidence of climatic niche shift during biological invasion. Ecology Letters 10:701-709.

Clark, J. S., et al. 1998. Reid's paradox of rapid plant migration: Dispersal theory and interpretation of paleoecological records. BioScience 48:13-24.

Clark, J. S., M. Lewis, and L. Horvath. 2001. Invasion by extremes: population spread with variation in dispersal and reproduction. American Naturalist 157:537-554.

Clark, J. S., M. Lewis, J. S. McLachlan, and J. HilleRisLambers. 2003. Estimating population spread: What can we forecast and how well? Ecology 84:1979-1988.

Cousens, R., C. Dytham, and R. Law. 2008. Dispersal in plants. A population perspective. Oxford University Press, Oxford, UK.

Dullinger, S., T. Dirnbock, and G. Grabherr. 2004. Modelling climate change-driven treeline shifts: relative effects of temperature increase, dispersal and invasibility. Journal of Ecology 92:241-252.

Elith, J., M. Kearney, and S. Philips. 2010. The art of modelling range-shifting species. Methods in Ecology and Evolution $1: 330-342$.

Evans, A., and T. Gregoire. 2007. A geographically variable model of hemlock woolly adelgid spread. Biological Invasions 9:369-382.

Fielding, A. H., and J. F. Bell. 1997. A review of methods for the assessment of prediction errors in conservation presence/ absence models. Environmental Conservation 24:38-49.

Fisher, R. A. 1937. The wave of advance of advantageous genes. Annals of Eugenics 7:355-369.

Fitzpatrick, M. C., A. D. Gove, N. J. Sanders, and R. R. Dunn. 2008. Climate change, plant migration, and range collapse in a global biodiversity hotspot: The Banksia (Proteaceae) of Western Australia. Global Change Biology 14:1337-1352.

Fitzpatrick, M. C., E. Preisser, A. Porter, J. Elkinton, L. Waller, B. Carlin, and A. Ellison. 2010. Ecological boundary detection using Bayesian areal wombling. Ecology 91:34483455.

Fitzpatrick, M. C., J. F. Weltzin, N. J. Sanders, and R. R. Dunn. 2007. The biogeography of prediction error: Why does the introduced range of the fire ant over-predict its native range? Global Ecology and Biogeography 16:24-33.

Franklin, J. 2010. Moving beyond static species distribution models in support of conservation biogeography. Diversity and Distributions 16:321-330.

Gallien, L., T. Münkemüller, C. H. Albert, I. Boulangeat, and W. Thuiller. 2010. Predicting potential distributions of invasive species: where to go from here? Diversity and Distributions 16:331-342.

Guisan, A., and W. Thuiller. 2005. Predicting species distribution: offering more than simple habitat models. Ecology Letters 8:993-1009. 
Hastings, A., et al. 2005. The spatial spread of invasions: new developments in theory and evidence. Ecology Letters 8:91101.

Hengeveld, R. 1988. Mechanisms of biological invasions. Journal of Biogeography 15:819-828.

Higgins, S. I., R. Nathan, and M. L. Cain. 2003. Are longdistance dispersal events in plants usually caused by nonstandard means of dispersal? Ecology 84:1945-1956.

Higgins, S. I., and D. M. Richardson. 1999. Predicting plant migration rates in a changing world: The role of longdistance dispersal. American Naturalist 153:464-475.

Higgins, S. I., D. M. Richardson, and R. M. Cowling. 1996. Modeling invasive plant spread: The role of plant-environment interactions and model structure. Ecology 77:20432054.

Huntley, B., P. Barnard, R. Altwegg, L. Chambers, B. W. T. Coetzee, L. Gibson, P. A. R. Hockey, D. G. Hole, G. F. Midgley, L. G. Underhill, and S. G. Willis. 2010. Beyond bioclimatic envelopes: dynamic species' range and abundance modelling in the context of climatic change. Ecography 33:621-626.

Johnson, D. M., A. M. Liebhold, P. C. Tobin, and O. N. Bjornstad. 2006. Allee effects and pulsed invasion by the gypsy moth. Nature 444:361-363.

Keith, D. A., H. R. Akçakaya, W. Thuiller, G. F. Midgley, R. G. Pearson, S. J. Phillips, H. M. Regan, M. B. Araújo, and T. G. Rebelo. 2008. Predicting extinction risks under climate change: coupling stochastic population models with dynamic bioclimatic habitat models. Biology Letters 4:560563.

Kenefic, L. S., and R. S. Seymour. 1999. Leaf area prediction models for Tsuga canadensis in Maine. Canadian Journal of Forest Research 29:1574-1582.

Klink, K. 1999. Climatological mean and interannual variance of United States surface wind speed, direction and velocity. International Journal of Climatology 19:471-488.

Koch, F. H., H. M. Cheshire, and H. A. Devine. 2006. Landscape-scale prediction of hemlock woolly adelgid, Adelges tsugae (Homoptera: Adelgidae) infestation in the southern Appalachian Mountains. Environmental Entomology 35:1313-1323.

Kot, M., M. A. Lewis, and P. van den Driessche. 1996. Dispersal data and the spread of invading organisms. Ecology 77:2027.

Mack, R. N. 1996. Predicting the identity and fate of plant invaders: Emergent and emerging approaches. Biological Conservation 78:107-121.

McClure, M. 1990. Role of wind, birds, deer, and humans in the dispersal of hemlock woolly adelgid (Homoptera: Adelgidae). Environmental Entomology 19:36-43.

McClure, M. 1991. Density-dependent feedback and population cycles in Adelges tsugae (Homoptera: Adelgidae) on Tsuga canadensis. Environmental Entomology 20:258-264.

McClure, M. S. 1989. Evidence of a polymorphic life cycle in the hemlock woolly adelgid, Adelges tsugae (Homoptera: Adelgidae). Annals of the Entomological Society of America 82:50-54.

Meentemeyer, R. K., B. L. Anacker, W. Mark, and D. M. Rizzo. 2008. Early detection of emerging forest disease using dispersal estimation and ecological niche modeling. Ecological Applications 18:377-390.

Meentemeyer, R. K., N. J. Cunniffe, A. R. Cook, J. A. N. Filipe, R. D. Hunter, D. M. Rizzo, and C. A. Gilligan. 2011. Epidemiological modeling of invasion in heterogeneous landscapes: spread of sudden oak death in California (1990-2030). Ecosphere 2:1-24.

Morin, R., A. Liebhold, and K. Gottschalk. 2009. Anisotropic spread of hemlock woolly adelgid in the eastern United States. Biological Invasions 11:2341-2350.
Orwig, D. A., D. R. Foster, and D. L. Mausel. 2002. Landscape patterns of hemlock decline in New England due to the introduced hemlock woolly adelgid. Journal of Biogeography 29:1475-1487.

Paradis, A., J. Elkinton, K. Hayhoe, and J. Buonaccorsi. 2008. Role of winter temperature and climate change on the survival and future range expansion of the hemlock woolly adelgid (Adelges tsugae) in eastern North America. Mitigation and Adaptation Strategies for Global Change 13:541554.

Parker, B. L., M. Skinner, S. Gouli, T. Ashikaga, and H. B. Teillon. 1999. Low lethal temperature for hemlock woolly adelgid (Homoptera: Adelgidae). Environmental Entomology 6:1086-1091.

Parmesan, C., and G. Yohe. 2003. A globally coherent fingerprint of climate change impacts across natural systems. Nature 421:37-42.

Pearce, J., and S. Ferrier. 2000. Evaluating the predictive performance of habitat models developed using logistic regression. Ecological Modelling 133:225-245.

Pearson, R. G., and T. P. Dawson. 2003. Predicting the impacts of climate change on the distribution of species: Are bioclimate envelope models useful? Global Ecology and Biogeography 12:361-371.

Pitt, J. P. W., S. P. Worner, and A. V. Suarez. 2009. Predicting Argentine ant spread over the heterogeneous landscape using a spatially explicit stochastic model. Ecological Applications 19:1176-1186.

Preisser, E., A. Lodge, D. Orwig, and J. Elkinton. 2008. Range expansion and population dynamics of co-occurring invasive herbivores. Biological Invasions 10:201-213.

R Development Core Team. 2009. R: A language and environment for statistical computing. R Foundation for Statistical Computing, Vienna, Austria. http://www. r-project.org

Santee, W. R., and C. D. Monk. 1981. Stem diameter and dry weight relationships in Tsuga canadensis (L.) Carr. Bulletin of the Torrey Botanical Club 108:320-323.

Shields, K. S., and C. A. Cheah. 2005. Winter mortality in Adelges tsugae populations in 2003 and 2004. Pages 354-356 in Proceedings of the 16th U.S. Department of Agriculture interagency research forum on gypsy moth and other invasive species. 18-21 January 2005, Annapolis, Maryland. K. W. Gottschalk, editor. USDA Forest Service General Technical Report NE-337.

Skarpaas, O., and K. Shea. 2007. Dispersal patterns, dispersal mechanisms, and invasion wave speeds for invasive thistles. American Naturalist 170:421-430.

Skellam, J. G. 1951. Random dispersal in theoretical populations. Biometrika 38:196-218.

Skinner, M., B. L. Parker, S. Gouli, and T. Ashikaga. 2003. Regional responses of hemlock woolly adelgid (Homoptera: Adelgidae) to low temperatures. Environmental Entomology 32:523-528.

Stoetzel, M. 2002. History of the introduction of Adelges tsugae based on voucher specimens in the Smithsonian Institute National Collection of Insects. Page 12 in Symposium on the Hemlock Woolly Adelgid in Eastern North America. USDA Forest Service, New Brunswick, New Jersey, USA.

Thuiller, W., C. Alberta, M. Araújo, P. Berry, M. Cabeza, A. Guisan, T. Hickler, G. Midgley, J. Paterson, F. Schurr, M. Sykes, and N. Zimmermann. 2008. Predicting global change impacts on plant species' distributions: future challenges. Perspectives in Plant Ecology, Evolution and Systematics 9:137-152.

Trotter, R. T., and K. S. Shields. 2009. Variation in winter survival of the invasive hemlock woolly adelgid (Hemiptera: Adelgidae) across the eastern United States. Environmental Entomology 38:577-587. 
Turner, M. G., Y. Wu, W. H. Romme, and L. L. Wallace. 1993. A landscape simulation model of winter foraging by large ungulates. Ecological Modelling 69:163-184.

USGS (U.S. Geological Survey). 1999. Digital representation of "Atlas of United States Trees" by Elbert L. Little, Jr. U.S. Geological Survey Professional Paper 1650. http://esp.cr. usgs.gov/data/atlas/little/
Walther, G. R., E. Post, P. Convey, A. Menzel, C. Parmesan, T. J. C. Beebee, J. M. Fromentin, O. Hoegh-Guldberg, and F. Bairlein. 2002. Ecological responses to recent climate change. Nature 416:389-395.

With, K. A. 2002. The landscape ecology of invasive spread. Journal of the Society for Conservation Biology 16:11921203.

\section{Supplemental Material}

\section{Appendix A}

Description of how maps of hemlock distribution and abundance were developed (Ecological Archives A022-030-A1).

\section{Appendix B}

Description of how hemlock mortality in infested cells was modeled (Ecological Archives A022-030-A2).

\section{Appendix C}

Description of how annual maps of mean winter temperature were developed (Ecological Archives A022-030-A3).

\section{Appendix D}

Description of field data collection and analyses used to estimate hemlock woolly adelgid (HWA) reproduction and survival rates (Ecological Archives A022-030-A4).

\section{Appendix E}

Description of the estimation of the dispersal-distance probability density function using maximum likelihood (Ecological Archives A022-030-A5).

\section{Appendix F}

Animated version of Fig. 2 showing spatiotemporal changes in probability of HWA infestation (Ecological Archives A022-030A6).

\section{Appendix G}

Animation of spatiotemporal changes in HWA population size (Ecological Archives A022-030-A7).

\section{Supplement}

R source code used for spread simulations (Ecological Archives A022-030-S1). 